\title{
Farmers' reactions to the internationalisation of cooperatives
}

Petri Ollila ${ }^{1}$, Jerker Nilsson ${ }^{2}$ and Sebastian Hess ${ }^{3}$

\author{
${ }^{1}$ Department of Economics and Management, University of Helsinki, PL. 27, 00014 Helsinki, Finland \\ ${ }^{2}$ Department of Economics, Swedish University of Agricultural Sciences, P.O. Box 7013, SE-750 07 Uppsala, Sweden \\ ${ }^{3}$ Department of Economics, Swedish University of Agricultural Sciences, P.O. Box 7013, SE-750 07 Uppsala, Sweden \\ e-mail: petri.ollila@helsinki.fi.
}

\begin{abstract}
This study examined the extent to which farmer cooperatives enjoy social capital within their memberships as they become internationalised. The empirical basis was a survey of farmers in Finland. Findings from limited dependent variable regression models suggest that the farmers who are most loyal to their cooperatives tend to oppose its foreign investments. Another group of farmers tended to switch membership status between different cooperatives, and a third group tended to opt out of cooperatives. The two latter categories were characterised by a lower level of social capital, and both of them welcomed the cooperatives' international operations. This finding was more significant for individual farm types than the social capital-linked opposition to internationalisation. A general conclusion is that the internationalisation of cooperatives seems to affect the members' trust in the cooperative differently. Thus there is increasing heterogeneity within the memberships which may give rise to governance problems.
\end{abstract}

Key words: Agricultural cooperative, internationalisation, social capital, Multi-Nominal Logit model, Finland

\section{Introduction}

This study investigated members' behaviour in relation to farmers' cooperatives, which have sizeable international operations, and deviate from the traditional cooperative model. Traditional cooperatives are organised according to cooperative principles with roots in the Rochdale Society, the Raiffeisen movement and the Schulze-Delitzsch movement (Barton 1989). Hence members have equal voting power, and the cooperatives follow a principle of equal treatment of members, have mainly unallocated funds, etc. It is often claimed that members refer to various sets of so-called cooperative values. Examples of what have been described as cooperative values are equality, independence, mutual self-help, equity, and democracy (Calvert 1959, Craig 1993, Hakelius 1996).

The traditional cooperative model is challenged when cooperatives embark on a route towards international operations in the sense that they own foreign production facilities, processing products supplied by farmers in the host countries (Bijman et al. 2012a, 2012b). To finance the foreign operations some cooperatives have enrolled external investors. A firm that is owned by both farmers and external financiers will, however, have built-in conflicts (Bont and Poppe 2012, Pyykkönen and Ollila 2012). Likewise, when farmers have invested in another country to process products from non-member farmers there are problems of interest alignment.

Strategies implying poor interest alignment are likely to lead to tensions and weak governance (Hendrikse and Feng 2013). "[I]n determining whether the costs of ownership are manageable for a given class of patrons, homogeneity of interest appears to be an especially important consideration" (Hansmann 1996, p. 288). As diverse patron categories have different interests, there are poorer conditions for trust and other expression of social capital within the membership, whereby the ownership costs are likely to be high in internationalised farmer co-operatives.

The aim of this study was to explore to which extent farmer cooperatives enjoy different kinds of social capital within their memberships as these cooperatives are developing towards more internationalised business operations. This seems to be the first study to analyse social capital among the members of internationalised cooperatives.

The next section lays the theoretical ground for the study in terms of the social capital paradigm. This is followed by presentations of the empirical basis and data collection. The variables contained in the questionnaire are then described and the results of the econometric computations are presented, summarised and discussed. Finally, some conclusions are drawn. 


\section{The social capital paradigm Social capital}

Putnam (2000, p. 19) defines social capital as "social networks [among individuals] and the norms of reciprocity and trustworthiness that arise from them". He continues: "Just as a screwdriver (physical capital) or a college education (human capital) can increase productivity (both individual and collective), so too social contacts affect the productivity of individuals and groups".

Trust is considered to be the foremost indicator of social capital (Woolcock 1998). If two actors trust each other and have good reasons for that, they can easier engage in productive collaboration. The collaboration may take place between different farmers within a cooperative framework, between a member and the cooperative as such, between a member and the cooperative's board or management, etc. For a joint project to be fruitful for all parties, it is necessary to build up relationships characterised by trust. The development of trustful relations is, however, a long-term process.

For a cooperative or any other business firm to be able to conduct various activities there is a need not only for financial capital, but also for social capital (and human, physical, etc.). Farmers would scarcely belong to a cooperative if they do not believe that their cooperative will pay for the products they deliver, if they do not believe that the leadership is honest, if they do not support the cooperative's bylaws, and if they do not consider their investments in the cooperative to be safe.

Trust reduces both transaction costs and agency costs in interpersonal and organisational settings. It decreases individuals' and organisations' costs of insuring themselves against deceitful behaviour, both in social life and in business relations. Investments in social capital create continuity and loyalty in relationships so that when something unexpected and negative happens, social capital facilitates a solution (Stickel et al. 2009).

Many authors distinguish between two categories of social capital; Bonding capital and Bridging capital (Adler and Kwon 2002, Payne et al. 2011). Bonding capital exists in socially close relationships within a collective such as a family, a friendship group, an organisational unit, or a religious community. It is based on a spirit of community within the collective. Bonding capital is often largely emotion-based.

Bridging capital can be characterised as bridges between actors within different collectives. The bridges may connect asymmetrical bodies, such as a boss and an employee, a teacher and a student, or long-term business partners. Relations between cooperative members and a cooperative leadership as well as between different members are probably mainly bridging capital, but many members may also consider their relationship with the cooperative as being of a bonding capital nature. Hence, the two concepts may be overlapping in a cooperative context (Nilsson et al. 2011).

Linking capital exists in a third category of human interaction (Robison et al. 2002), although the parties have so weak relationships that this concept is normally not considered a class of social capital. It is related to semi-socially close relationships, can be characterised by moderate-term commitment and exists in ordinary business relationships. Linking capital can include trust and collegiality, e.g. between co-workers who are performing similar tasks, or different members of a cooperative society.

The changing relations between cooperatives and their members may be interpreted in terms of a change in the relative proportions of bonding, bridging and linking capital. For example, members' fading ideology and increasing business orientation may prompt a conversion from bonding capital or bridging capital to linking capital. In particular, the internationalisation of cooperatives can be expected to result in reduced amounts of social capital.

\section{Indicators of social capital}

The amount of empirical research about members' opinions of their cooperatives is large. These studies comprise many constructs, which are related to social capital, for example involvement (Bravo-Ureta and Lee 1988, Cain et al. 1989, Klein et al. 1997, Österberg and Nilsson 2009), satisfaction (Arcas-Lario et al. 2014), trust (Burt and Wirth 1990, Enander et al. 2010), and commitment (Fulton and Adamowicz 1993, Mensah et al., 2012). Other social capital-related concepts that appear in previous research about farmers' view of cooperatives are attitudes, 
knowledge, preferences, solidarity and loyalty (Jensen 1990, Misra et al. 1993, Klein et al. 1997, Richardset al. 1998, Zeuli and Betancor 2005, James and Sykuta 2006, Barbaud-Didier et al. 2012).

This study defined seven indicators of social capital with potential relevance for cooperative strategies, and in addition three types of members' opinions about internationalisation. Out of these seven indicators, four and three refer to Bonding or Bridging capital, and Linking capital, respectively: Bonding capital exits when members have a strong attachment to their cooperative and to fellow members, the leadership, or the local community whereas bridging capital expresses a mediate attachment. The four indicators chosen are Ideology, Cooperative experience, Security, and Reliability. Hereafter, it is explained how these indicators have been defined and how each was empirically operationalised in the questionnaire:

- Ideology (“Cooperative ideology keeps me a member of my cooperative"): Cooperative ideology is a conception that cooperative firms are good for the farmers (Hakelius 1996). It is therefore linked to a set of values among the membership. The more that the farmers consider themselves to have a cooperative ideology the more trust they have in the management of the cooperative (Borgen 2001). Members with an ideological conviction are committed and willing to make short-term sacrifices in order to reap long-term benefits. Cooperative ideology may have positive effects not only for the cooperative firm but also for the members because trust reduces conflict levels (Shaffer 1987, Staatz 1987, Ollila 1989). The ideological view of cooperatives also contributes to financial stability as members accept a large amount of unallocated equity capital (Fahlbeck 2007). Ideology among members increases members' risk willingness (Davis and Bartkus 2009).

- Cooperative experience ("Experience of long-term cooperation keeps me a member of my cooperative"): Cooperative loyalty is likely to develop over time, and loyal members remain within their cooperatives for an extended period of time. The farmers get experiences from the business they conduct with the cooperatives and from the interaction they have with each other. An important factor behind members' experience of a cooperative is whether they feel that they have an influence in the governance (Bhuyan and Leistritz 2001, Lang and Fulton 2004, Österberg and Nilsson 2009).

- Security ("Membership is a shelter against large processing firms"): According to several studies members estimate the fact that cooperatives constitute an assured marketing channel. This may even be more important than the price levels (Bravo-Ureta and Lee 1988, Cain et al. 1989, Jensen 1990). This appreciation of security represents rational behaviour from the members' side. Without their cooperative they might not have a buyer of the agricultural products, or they might have an investor-owned partner that they cannot rely on. This is a question about protecting the farmers' transaction specific assets.

- Reliability ("The information that I obtain from my cooperative is reliable"): When the amount of social capital within the membership is high, the members have much confidence in the cooperative leadership. An indicator of such confidence is that they appreciate the information from the cooperative. They may have a feeling of cooperative identity (James and Sykuta 2005, Nilsson et al. 2009).

As linking capital implies that members regard the cooperative as any other trading partner the indicators are Speculative behaviour, Power ambitions, and Non-loyalty.

- Speculative behaviour ("The cooperative membership is a pure business relationship to me"): When the social capital is weakened the individuals are to an increasing degree trying to satisfy their own interests at the expense of others (Hansen et al. 2002, Nilsson et al. 2009). Free-riding is harmful for to the cohesion in a membership.

- $\quad$ Power ambitions ("A possibility to use political power for advancing my own interests through the cooperative keeps me as a member of my cooperative"): Staatz (1984) suggests that directors may prevent a cooperative from conducting efficiency-enhancing measures because the resulting organisational structure may threaten their power position. Fulton and Hueth (2009) report from cases when directors have worked to dissolved cooperatives as thereby they may get their full share of the cooperative's net assets paid out in cash whereas they would get only their invested stock in case they were to exit.

- Non-loyalty ("If I get the same advantages through delivering to another buyer, I do not have any problem switching the buyer"): In situations when a cooperative has limited amount of social capital in its membership it is likely that the farmer-members have a high propensity to switch to another trading partner (Gray and Kraenzle 1998, Bhuyan 2007). 
The amount of social capital among farmers may be related to the members' views of the cooperatives' internationalisation in different respects. In this study three types of member opinions are identified:

- Members' opinions about structural attributes of the internationalised cooperatives;

- Members' opinions about the strategies of the internationalised cooperatives;

- Members' opinions about how the cooperatives' internationalisation affects the competitive pressure they are facing.

\section{Empirical basis}

\section{Finnish agricultural cooperatives}

The relationship between the amount of social capital that cooperatives have in their memberships and the farmers' opinions about the internationalisation of cooperatives is investigated through an empirical study of Finnish farmers. The Finnish cooperatives operate nationwide but they also have sizeable operations in most of the countries around the Baltic Sea, not only exporting goods from Finland but also processing products sourced from farmers in the host countries. The foreign operations are, however, run inside fully or partially owned subsidiaries. There is no case where Finnish and foreign farmers belong to the same cooperative.

The Finnish cooperatives have few processing activities of their own. Processing and marketing are allocated to limited liability companies, which are owned either jointly by a number of cooperatives (dairy) or by cooperatives together with investors via the Helsinki Stock Exchange (meat, forestry). As cooperatives in the latter category do not have full ownership and full control of the business operations, they do not comply with the generally respected definition of cooperatives (Dunn 1988).

Having only partial ownership and partial control of the processing and marketing operations the Finnish farmer have to adapt to the interests of the external investors. Therefore they fall within the concept of Farmer-Controlled Business, FCB. An FCB is a firm which has its ownership shared between farmers (individually or via a cooperative society) and non-farmer investors, although farmers have the majority of the seats in the Board of Directors (Hind 1999, Chaddad and Cook 2007, Hess et al. 2013). The Finnish cooperative societies have the sole or dominant task of owning stock in limited liability processing companies.

As an internationally operating FCB must balance the farmers' interest in obtaining good prices and services with the external investors' interest in capital returns, the amount of social capital that farmers have in the processing firms is likely to be less than in a traditional cooperative. Likewise, the international operations could be expected to be poorly understood by the farmer-members, which may cause a low amount of social capital.

Even though Finnish cooperatives do not have full control over the processing firms in which they own stock, the farmer-members consider these firms to have cooperative status. This may indicate that there is some social capital among the membership. In accordance with the Finnish terminology, in the following the FCBs are called 'cooperatives'.

\section{Data collection}

Data were collected via a mail survey sent to a representative sample of Finnish farmers, both members of cooperatives and non-members. The questions for this study were included in one of Gallup Finland's three-monthly questionnaires, which are used in omnibus surveys of farmers. The questionnaire was sent to sample of 2,400 farmers in summer 2010. The total number of responses received was 1,296 , corresponding to a response rate of 47.3\%. However, many respondents had not fully completed the questionnaire, so in some instances the missing answers on continuous variables could be replaced by the sample mean. This was the case for the variables "age of the respondent" and "area under cultivation", in which 52 and 115 missing observations, respectively, have been replaced by the sample mean of this variable. Replacing missing values is common in order to not lose the corresponding observations entirely. The sample mean does not bias the available information from the non-missing observations. Alternatively, missing values could have been replaced based on predictions from auxiliary regressions or related imputation methods. For categorical answers another category has been included in the case of missing values (dummy $=1$ if value missing). 
Reliability and construct validity were assessed for each set of survey questions (see Appendix); these sets reflected certain types of social capital or opinions regarding internationalisation. As commonly done, reliability has been assessed based on Cronbach's alpha in order to test the extent to which respondents understand the survey question in the same way, so that their answers were comparable. Construct validity has been tested by using standard Factor Analysis. A high share of variance explained by the first Eigenvalue indicates in this context the extent to which a certain group of variables actually refers to the same underlying construct (e.g. "Linking capital").

Results from Cronbach's alpha (1) and from the variance explained by the first Eigenvalue (2), respectively, are for Bonding and Bridging capital $(1)=0.93,(2)=81.12$, for linking capital $(1)=0.79$ and $(2)=70.97$, for opinions about structural attributes of internationalised cooperatives $(1)=0.81,(2)=65.97$, for opinions about the strategies of the internationalised cooperatives $(1)=0.90$ and $(2)=76.98$, and for opinions about how the cooperatives' internationalisation affects the competitive pressure $(1)=0.90$ and $(2)=67.54$.

These findings show that overall respondents understood the questions in a similar way, and the assignment of survey questions to the specific groups (Appendix) is meaningful, with the reliability and validity of Linking capital relatively weak and the ones of Bonding and Bridging capital relatively strong. Further descriptive analysis shows that the average age of respondents was 54 years and the vast majority, 85 per cent, were men, meaning that the sample appeared to be fairly representative for the population of Finnish farmers. The average acreage of agricultural land farmed by the respondents was 49 hectares and the average number of dairy cows per herd was 26 . Again, these figures indicate that the sample did not deviate greatly from the national averages, which are 46 hectares and 27 cows. The farmers surveyed belonged to one or several different organisations: 29 per cent belonged to a dairy cooperative, 27 per cent to a meat cooperative and 59 per cent to a forestry cooperative.

\section{Variables}

\section{Dependent variables}

The analyses comprised four models. The first three tested the relationship between farmers' membership of different categories of cooperative on the one hand, and a number of potentially explanatory factors on the other. These were the farmers' stated level of social capital, their opinions about three aspects of the cooperatives' internationalisation, their socioeconomic characteristics and attributes of their farm enterprises. Hence the questionnaire comprised several categories of questions. Membership of cooperatives was measured by posing the following question to respondents: 'In which of the following cooperatives are you a member?' Respondents could select none, one or multiple answers among the nine alternatives:

1: One of the eighteen local or regional dairy cooperative societies which together own all the stock of the limited liability processing company Valio.

2, 3, 4: One of the three cooperative societies (Itikka, Lihakunta and Pohjanmaan liha), which together own the meat processing limited liability company Atria.

5: Järvi-Suomen Portti, a traditionally organised cooperative in the meat industry. (At present a part of HKScan.)

6: LSO, a cooperative society that dominates the board of the limited liability company meat processing HK Scan, although that processing firm is also part-owned by a Swedish cooperative society and investors via the Helsinki Stock Exchange

7: Munakunta, a traditionally organised egg packaging and marketing cooperative with about 50 per cent of the Finnish market. It has also operations in Estonia.

8: Metsäliitto, a major forestry cooperative part-owned by investors via the Helsinki Stock Exchange.

9: Any other cooperative. 
A second survey question was 'Which of the aforementioned cooperatives is your main sales channel?' The respondents' opinions about internationalisation was captured by the agree/disagree statement 'My cooperative must invest in internationalisation'. Information obtained from answers to these three questions was used to construct the following four dependent variables of the analysis:

$Y_{1} \quad$ Multinomial variable capturing which of the cooperative categories 1-8 that a farmer belonged to and an additional $\left(9^{\text {th }}\right)$ category for respondents who did not indicate membership of any of these cooperatives (this ninth category is the same as $Y_{3}=1$ ).

$\mathrm{Y}_{2} \quad$ Ordinal variable indicating how many of the categories 1-9 that a farmer belonged to. The number of memberships may be an indicator of the amount of social capital, together with other indicators.

$\mathrm{Y}_{3} \quad$ Binary variable indicating whether the farmer was a member of any of the cooperatives in categories 1-8 (in that case $\mathrm{Y}_{3}=0$ ) or in any other cooperative (including no or omitted answer to 9 as long as answers to other questions were provided).

$\mathrm{Y}_{4} \quad$ Ordinal variable indicating whether the respondent believed that a cooperative must invest for internationalisation. Answers were provided on a Likert scale ranging from $1=$ 'Fully disagree' to 5 = 'Fully agree'.

The four categorical (discrete) variables $\left\{Y_{1}, Y_{2}, Y_{3}, Y_{4}\right\}$ reflect different degrees of involvement in the categories 1-9 and related opinions about internationalisation $\left(Y_{4}\right)$. The involvement in cooperatives ranges from no $\left(Y_{3}\right)$ to multiple memberships $\left(Y_{2}\right)$ and distinguishes the main sales channels $\left(Y_{1}\right)$ from other cooperative memberships. Based on these variables, the empirical model takes the following general form:

$y^{*}=X^{\prime} \beta+\varepsilon$

where $y^{*}$ is an element from $\left\{Y_{1}, Y_{2}, Y_{3}, Y_{4}\right\}$, the stochastic errors (residuals) are contained in $\varepsilon$, and $B$ is a vector of coefficients to be estimated on the vector of covariates $X$.

\section{Independent variables}

The vector of covariates $\boldsymbol{X}$ in equation 1 is composed of the following main sets of variables: Farmer characteristics, Farm characteristics, Social capital, Opinions about how the cooperatives' internationalisation affects the competitive pressure, Opinions about the strategies of the internationalised cooperatives, Opinions about structural attributes of internationalised cooperatives. Each variable in these sets corresponds to a specific survey question. All survey questions are described and, for easier comparison with the regression results, are consecutively numbered in the Appendix.

\section{Analyses and results}

In the analysis, four different logit models were fitted to the dependent variables $\left\{Y_{1}, Y_{2^{\prime}} Y_{3^{\prime}}, Y_{4}\right\}$, using explanatory variables which reflected categories on farmer, farm, social capital and opinions. Potential multicollinearity between explanatory variables was tested for, based on variance inflation factors (VIF), with VIF values up to the threshold level 10 being tolerated. In the next step, the model was fitted and insignificant explanatory variables were gradually removed according to the highest $p$-values first. After each removal, the model was re-estimated accordingly until model selection criteria did not improve any further.

\section{Main sales channel (model 1)}

The first step of the analysis was a multi-nominal logit model (model 1). Due to the length of tables, the full set of model results is omitted here, but is available from the authors upon request. The overall explanatory power of this model was satisfactory, with about $79 \%$ of cases predicted correctly. The model indicated that a farm's main sales channel was best explained by socioeconomic factors relating to the farmer, such as age, gender and remaining time to retirement age. These variables proved to be significant for almost all of the nine model equations. In addition, farm level specialisation and acreage determined the main sales channel. However, stated opinions and variables that captured the level of social capital appeared less strong in terms of explanatory power and were insignificant in many of the nine equations. 
This finding was expected, because a farm's main sales channel should reflect the farm's specialisation or diversification profile. For instance, a dairy farm's main sales channel is likely to be a dairy cooperative. Thus a combination of farmer and farm characteristics determines the main sales channel: Social capital typically does not play any role for the farmer's choice of production. Instead, farms specialise according to their comparative advantage, which should be determined by experience and available resources and infrastructure.

\section{Number of memberships in cooperatives (model 2)}

The second step was an ordered logit model in which the dependent variable represented the stated number of cooperative memberships that were reported by survey respondents $\left(\mathrm{Y}_{2}\right)$. In contrast to multi-nominal models, ordered logit models are capable of reflecting the fact that the levels of the dependent variable represent an increasing order. However, a disadvantage of ordered logit models is that neither the magnitude nor the sign of the estimated coefficients receives a direct interpretation (e.g. Greene 2012). Instead, marginal (or partial) effects of each explanatory variable on the dependent variable have to be computed. Table 1 presents the calculated marginal effects according to the Delta method in Stata. Displayed are average marginal effects; a full breakdown for each category of the dependent variable is available on request.

An inspection of the marginal effects revealed that the number of memberships in cooperatives was only partly explained by the number of different animal production enterprises on the farm and the total production volume of animals and crops. Many of these variables appeared insignificant, with only part-time farming and number of sows appearing statistically significant and showing a positive marginal effect. According to this positive marginal effect, a one-unit increase in each of these variables increased the probability of the farmer being a member of multiple cooperatives. In other words, part-time farmers and pig breeders were likely to be members of several cooperative categories. In contrast, the number of dairy cows showed a negative relationship with the dependent variable, indicating that farms with many dairy cows were likely to be members of few, one or no cooperative.

The explanatory power of the stated opinions about competition and cooperative internationalisation strategies was much stronger than that of farm and farmer variables. Respondents who did not view their neighbour as a competitor tended to be a member of more cooperatives, while those who believed that the cooperative should return its economic surplus to its members rather than investing it abroad had fewer memberships. Similarly, respondents who believed that imports of meat and dairy products should be prohibited had rather few memberships, as did those who were of the opinion that only members should be allowed to deliver to a certain cooperative.

In contrast, respondents who believed that they should be able to become equal members of cooperatives in foreign countries tended to have rather many memberships. This also applied to respondents who agreed that a cooperative is primarily a platform for them to pursue their personal interest in the execution of power and the advancement of benefits to self. Likewise, respondents who stated they easily switch cooperatives tended to have more memberships than others. Respondents who declared that they had long experience of cooperatives and those who stated that they have a cooperative ideology or find market information from their cooperatives to be rather trustworthy had rather few cooperative memberships, as indicated by the negative marginal effects.

In conclusion, the ordered logit model analysis suggested that one sub-group of respondents can be characterised by rather high levels of social capital in terms of cooperative ideology, long-term experience and reluctance to switch between cooperatives.

The results obtained with the model (Table 1 ) indicate the existence of another group of farmers with the opposite opinion about cooperatives: These farmers are not characterised by Bonding or Bridging capital as their opinions are described by opinions about perceived competition, openness to cooperative internationalisation and a strong sense of advancement of self-interest. This group of respondents tended to be characterised by a rather large number of cooperative memberships. 
Table 1: Marginal effects ( $\mathrm{dy} / \mathrm{dx}$ ) according to the ordered logit model (model 2: Dependent variable = 'Number of cooperatives that the respondent supplies'

\begin{tabular}{|c|c|c|c|c|c|}
\hline Delta method & $\mathrm{dy} / \mathrm{dx}$ & Std. Err. & $z$ & $p>z$ & \\
\hline \multicolumn{6}{|l|}{ Farmer and farm characteristics } \\
\hline (1) Age & -0.0003 & 0.0006 & -0.4100 & 0.6800 & \\
\hline Part-time & 0.0545 & 0.0077 & 7.0600 & 0.0000 & $* * *$ \\
\hline Approaching retirement age & -0.0129 & 0.0085 & -1.5200 & 0.1280 & \\
\hline (2) Gender & -0.0130 & 0.0154 & -0.8400 & 0.3990 & \\
\hline (3) Acreage (hectares) & 0.0002 & 0.0002 & 1.2500 & 0.2110 & \\
\hline No. of cows & -0.0032 & 0.0006 & -5.3500 & 0.0000 & $* * *$ \\
\hline No. of sows & 0.0006 & 0.0002 & 3.0500 & 0.0020 & $* * *$ \\
\hline No. of piglets & 0.0000 & 0.0000 & -1.1500 & 0.2490 & \\
\hline No. of laying hens & 0.0000 & 0.0000 & -0.6100 & 0.5440 & \\
\hline No. of poultry & 0.0000 & 0.0000 & -0.3400 & 0.7350 & \\
\hline No. of other animals & 0.0000 & 0.0031 & -0.0100 & 0.9890 & \\
\hline (4) Count of animal types (Diversity) & -0.0173 & 0.0089 & -1.9400 & 0.0520 & \\
\hline \multicolumn{6}{|l|}{ Social capital indicators } \\
\hline Member say they have a cooperative ideology & 0.0119 & 0.0070 & -1.7000 & 0.0880 & $*$ \\
\hline Experience of cooperatives & -0.0129 & 0.0068 & -1.9000 & 0.0580 & $*$ \\
\hline Advancing self-interest & 0.0137 & 0.0070 & 1.9600 & 0.0500 & $* *$ \\
\hline Membership as a shelter & -0.0032 & 0.0063 & -0.5100 & 0.6100 & \\
\hline Business relationship & -0.0156 & 0.0051 & -3.0600 & 0.0020 & $* * *$ \\
\hline Switch buyer easily & 0.0119 & 0.0047 & 2.5300 & 0.0110 & $* *$ \\
\hline Cooperative information reliable & -0.0210 & 0.0050 & -4.1700 & 0.0000 & $* * *$ \\
\hline \multicolumn{6}{|c|}{ Opinions on structural attributes of internationalised cooperatives } \\
\hline Foreign members dictate contract & -0.0035 & 0.0081 & -0.4300 & 0.6650 & \\
\hline Equal membership in foreign cooperative & 0.0188 & 0.0093 & 2.0300 & 0.0420 & $* *$ \\
\hline Satisfied with foreign cooperative & 0.0038 & 0.0066 & 0.5700 & 0.5690 & \\
\hline Fair for cooperative to define foreign deliveries & -0.0117 & 0.0078 & -1.5000 & 0.1330 & \\
\hline Foreign suppliers should be members & 0.0017 & 0.0051 & 0.3300 & 0.7420 & \\
\hline Satisfied with foreign members & -0.0091 & 0.0092 & -0.9900 & 0.3240 & \\
\hline \multicolumn{6}{|l|}{ Opinions on strategies of internationalised cooperatives } \\
\hline Return surplus to members & -0.0151 & 0.0043 & -3.5100 & 0.0000 & $* * *$ \\
\hline Prohibit imports of meat and milk & -0.0076 & 0.0037 & -2.0500 & 0.0410 & $* *$ \\
\hline Suppliers should be members & -0.0188 & 0.0056 & -3.3600 & 0.0010 & $* * *$ \\
\hline Foreign suppliers should be members & -0.0070 & 0.0093 & -0.7500 & 0.4520 & \\
\hline \multicolumn{6}{|c|}{ Opinions on internationalised cooperatives' influence on farmers' competitive pressure } \\
\hline Neighbours do not compete & 0.0329 & 0.0117 & 2.8200 & 0.0050 & $* * *$ \\
\hline Members of my cooperative do not compete & -0.0481 & 0.0147 & -3.2800 & 0.0010 & $* * *$ \\
\hline Members of other cooperatives do not compete & 0.0183 & 0.0140 & 1.3100 & 0.1900 & \\
\hline Producers selling to IOFs do not compete. & 0.0124 & 0.0125 & 0.9900 & 0.3240 & \\
\hline Foreign farmers in my field do not compete & -0.0174 & 0.0130 & -1.3300 & 0.1830 & \\
\hline Foreign farmers in my cooperative do not compete & 0.0152 & 0.0128 & 1.1900 & 0.2340 & \\
\hline
\end{tabular}

Mean dependent var. 1.331790, S.D. dependent var. 0.975899, Log-likelihood 1301.257, Akaike criterion 2688.515, Number of cases 'correctly predicted' $=748(57.7 \%)$, Pseudo $\mathrm{R}^{2}=0.2503$

Note: Numbers in front of explanatory variables refer to survey questions listed in Section "Independent Variables". 


\section{Low involvement in cooperatives (model 3)}

Model 3 used the same set of explanatory variables $X$ as models 1 and 2. However, the dependent variable of model $3\left(Y_{3}\right)$ most likely contains the largest measurement error, because 'No membership' could not be distinguished from unreported membership.

Therefore this variable was interpreted as an indicator of a very low level of involvement and low interest in cooperative membership, rather than as a definite measure of membership absence. Table 2 presents the results obtained using the binary probit model. The dependent variable took a value of 1 if the respondent did not indicate any memberships in cooperative categories 1-8, but chose category 9 'Other cooperatives'.

Table 2: Coefficients obtained with the binary probit model (model 3), robust standard errors. Dependent variable = 'Respondent did not report membership of any cooperative'

\begin{tabular}{|c|c|c|c|c|c|}
\hline & Coefficient & Std. Error & $\mathrm{z}$ & $p$-value & \\
\hline Const & 0.044680 & 0.616712 & 0.0724 & 0.94224 & \\
\hline (1) Age & 0.009225 & 0.008340 & 1.1061 & 0.26868 & \\
\hline Part-time & 0.359427 & 0.097396 & 3.6903 & 0.00022 & $* * *$ \\
\hline Approaching retirement age & -0.108004 & 0.108557 & -0.9949 & 0.31978 & \\
\hline (2) Gender & -0.092649 & 0.213077 & -0.4348 & 0.66370 & \\
\hline (3) Acreage (hectares) & -0.003467 & 0.002494 & -1.3899 & 0.16456 & \\
\hline No. of cows & -0.039461 & 0.015529 & -2.5410 & 0.01105 & $* *$ \\
\hline No. of sows & -0.001113 & 0.004713 & -0.2363 & 0.81320 & \\
\hline No. of piglets & -0.000273 & 0.000801 & -0.3404 & 0.73354 & \\
\hline No. of laying hens & -0.000000 & 0.000000 & -1.0825 & 0.27904 & \\
\hline No. of poultry & -0.002087 & 0.001274 & -1.6374 & 0.10154 & \\
\hline No. of other animal & 0.012690 & 0.037244 & 0.3407 & 0.73329 & \\
\hline (4) Count of animal types (Diversity) & -0.164669 & 0.144744 & -1.1377 & 0.25526 & \\
\hline (6) Experience of cooperatives & -0.266605 & 0.091558 & -2.9119 & 0.00359 & $* * *$ \\
\hline (7) Advancing self-interest & 0.242688 & 0.104219 & 2.3286 & 0.01988 & $* *$ \\
\hline (9) Business relationship & -0.155876 & 0.059081 & -2.6383 & 0.00833 & $* * *$ \\
\hline (11) Cooperative information reliable & -0.256517 & 0.062407 & -4.1103 & 0.00004 & $* * *$ \\
\hline (18) Return surplus to members & -0.143524 & 0.051481 & -2.7879 & 0.00531 & $* * *$ \\
\hline (21) Foreign suppliers should be members of my cooperative & -0.167281 & 0.059261 & -2.8228 & 0.00476 & $* * *$ \\
\hline (22) Neighbours do not compete & 0.190158 & 0.122903 & 1.5472 & 0.12181 & \\
\hline pende & Fadden $\mathrm{R}^{2}$ & \multicolumn{2}{|c|}{0.297204} & & \\
\hline Log-likelihood & \multicolumn{4}{|c|}{ Cases correctly predicted = $1095(84.5 \%)$} & \\
\hline
\end{tabular}

Note: Numbers in front of explanatory variables refer to survey questions listed in Section "Independent Variables".

The results obtained using model 3 showed a similar pattern to those obtained with model 2 but not with model 1. On controlling for the diversity and size of farms and the heterogeneity of the farming population (explanatory sets farm, farmer), only the number of dairy cows and the degree of part-time farming appeared significant. As with model 2, the effect of a larger number of dairy cows on the dependent variable was that dairy farms were less likely than other farms to fall into the category 'No cooperative membership or very little interest in it' $\left(=Y_{3}\right)$.

Whether a farmer abstained from cooperative membership did not seem to be related to the type of farm, the characteristics of the farmer or the degree of specialisation. Instead, the opinions stated and opinions revealed with respect to values and other components of social capital contributed by far the most to the explanatory power of this model. The coefficients obtained with model 3 showed similarities to the marginal effects obtained with the ordered logit model 2. The probability of a respondent reporting 'No cooperative membership' decreased with long-term experience of cooperatives, a preference for the distribution of cooperative's surplus to members, and the perception of cooperative market information as trustworthy. Respondents who viewed cooperatives as a platform to pursue their own economic interests were more likely not to be members of any cooperative, as in- 
dicated by a positive estimated coefficient for this explanatory variable. Overall, the results from model 3 were in line with those from the ordered logit model 2 . The estimated effects for social capital variables indicated that respondents with more social capital were members of fewer cooperatives. Contrary to this, statements that indicated a respondent opinion to be geared towards monetary profits and individual power tended to be related to membership of a larger number of cooperatives in model 2 and to no membership at all in model 3.

\section{Opinions about internationalisation (model 4)}

Having investigated the relationship between cooperative membership and social capital and opinions about international competition, the next analysis concerned respondents' opinions about cooperative internationalisation. For this purpose, the third dependent variable, the classes of responses to the statement 'My cooperative must invest in internationalisation' were analysed using an ordered logit model.

Model 4 had the same structure as equation 1 and the explanatory variables were initially the same sets (farmer, farm, social capital and opinions) forming $X$ as for the ordered logit model 2 (Table 3). The variables relating to opinions on international competition were retained as explanatory variables for opinions with respect to internationalisation, because it is desirable to control the fact that some or all of these questions may relate to the same unobserved underlying (latent) factor that determines farmers' opinions about cooperative investment for internationalisation. The model selection criteria provided in Table 3 refer to the actual ordered logit model and not to the marginal effects directly.

The results from this model indicated that stating a preference for cooperative internationalisation investment was statistically independent of individual characteristics of farmers, since the variables on age and gender were insignificant and were therefore removed from the model. However, the farm characteristic variables indicated that more diversified farmers were in favor of internationalisation, while large arable farms, especially egg and poultry producers tended to be on average against it. However, a breakdown of the marginal effects into each category of the dependent variable reveals a positive and significant relationship in the three highest categories, indicating that the largest farms are also significantly in favour of internationalisation; however, the average marginal effect (Table 3) turned out to be negative.

Membership of any of the cooperative categories 1-9 had no effect on the dependent variable. However, high levels of social capital indicators were related to disliking internationalisation. Farmers who declared themselves to be prepared to "switch buyer easily" may not share traditional cooperative values, but still seemed to be generally against investments in internationalisation. One interpretation may be that investments in internationalisation are perceived by some farmers as risky and in conflict with short-term profit maximisation of a cooperative. Respondents who disliked internationalisation did not have a strong perception of competition among farmers, and they wanted cooperatives to be 'closed shops' of members and to pay the cooperative's entire surplus to members.

The respondents who were opposed to cooperative internationalisation were against milk and meat imports and insisted that their own cooperative should only buy from domestic members. They also stated that foreign suppliers should be cooperative members. Only respondents who agreed that foreign cooperative members could dictate delivery contracts in Finland and those who believed that their cooperatives should be open to foreign members were explicitly in favour of cooperative investments in internationalisation.

In conclusion, the selection of significant variables in the ordered logit model (model 4) underlying Table 3 showed that farmers' opposition to internationalisation was significantly related to high levels of social capital. Fewer explanatory variables that explicitly explained the opinions welcoming investments in internationalisation could be identified. 
Table 3: Marginal effects $(d y / d x)$ from an ordered logit model (model 4): Dependent variable = 'My cooperative must invest for internationalisation'

\begin{tabular}{llllll}
\hline Delta method & $\mathrm{dy} / \mathrm{dx}$ & Std. Err. & $\mathrm{z}$ & $p>\mathrm{z}$ \\
\hline Farm characteristics & & & & & \\
(3) Acreage (hectares) & -0.0002 & 0.0001 & -2.2500 & 0.0240 & $*$ \\
No. of piglets & 0.0001 & 0.0000 & 1.5300 & 0.1250 & \\
No. of laying hens & -0.0148 & 0.0048 & -3.1100 & 0.0020 & $* * *$ \\
No. of poultry & -0.0014 & 0.0006 & -2.2700 & 0.0230 & $*$ \\
No. of other animals & 0.0057 & 0.0040 & 1.4200 & 0.1540 & \\
(4) Count of animal types (Diversity) & 0.0132 & 0.0062 & 2.1300 & 0.0330 & $*$ \\
Social capital indicators & & & & & \\
(8) Shelter in cooperative & -0.0087 & 0.0048 & -1.8000 & 0.0710 & $*$ \\
(10) Switch buyer easily & -0.0083 & 0.0035 & -2.3600 & 0.0180 & $*$ \\
(11) Cooperative information reliable & -0.0092 & 0.0045 & -2.0500 & 0.0400 & $*$ \\
Opinions about cooperatives' internationalisation & & & & & \\
(12) Foreign members define your contract & & & & & \\
(13) Equal member in that foreign cooperative & 0.0112 & 0.0064 & 1.7400 & 0.0820 & $*$ \\
(15) Your cooperative defines foreign producers' contracts & -0.0151 & 0.0066 & -2.2700 & 0.0230 & $*$ \\
(16) Foreign suppliers should be members & 0.0141 & 0.0058 & 2.4500 & 0.0140 & $*$ \\
(17) Satisfied with foreign members & -0.0471 & 0.0083 & -5.6900 & 0.0000 & $* * *$ \\
(18) Return surplus to members & -0.0254 & 0.0052 & -4.8800 & 0.0000 & $* * *$ \\
(19) Prohibit imports of meat and milk & -0.0195 & 0.0045 & -4.2900 & 0.0000 & $* * *$ \\
(20) Suppliers should be members & -0.0180 & 0.0044 & -4.0600 & 0.0000 & $* * *$ \\
(21) Foreign suppliers should be members of my cooperative & -0.0282 & 0.0056 & -5.0700 & 0.0000 & $* * *$ \\
(22) Neighbours do not compete & 0.0201 & 0.0079 & 2.5400 & 0.0110 & $*$ \\
(23) Members of my cooperative do not compete & -0.0151 & 0.0109 & -1.3800 & 0.1690 & $*$ \\
\hline
\end{tabular}

Log pseudo likelihood $=-1581.9109$, Pseudo $R^{2}=0.2515$, Number of cases predicted correctly: $53 \%$

Note: Numbers in front of explanatory variables refer to survey questions listed in Section "Independent Variables". The full results obtained with the ordered logit model are available from the authors upon request.

\section{Discussion}

Taking the findings from the four models together, a certain picture emerged about the relationship between the members' attributes and the social capital. As one would expect, the farmers' decisions about farm diversification, growth and choice of cooperatives as their main sales channel were not clearly related to any form of social capital. Farmers did not choose their branch of agricultural production based on sympathies for cooperatives. Instead, their choice of farm production enterprises was related to their personal characteristics and those of their farm.

However, after controlling the farm size, specialisation and farmer characteristics, it was found that the degree to which farmers were members of cooperatives still varied. Some farmers were members of more cooperatives than could be explained by e.g. the number of their main farm outputs. This variation was not explained by farm characteristics, but by farmers' amount of social capital. High levels of social capital resulted in the farmer being a member of one or few cooperatives, which were perceived as being of rather high value (e.g. trustworthy information, ideology). Farmers, characterised by much social capital in relation to cooperatives were opposed to cooperative investments in internationalisation. Farmers who embrace the traditional cooperative values want their cooperatives to work as traditionally functioning cooperatives, i.e. with closely member-related business, financed by unallocated capital, etc. (Borgen 2001, Fahlbeck 2007).

Farmers specialising in e.g. dairy production had a meaningful and often long membership in a cooperative. Those members had much at stake in their memberships and they have ensured that the relationship with their cooperative is good. It is reasonable to assume that such a relationship is bonding capital of nature. Hence, the results indicate that certain groups of farmers have levels of bonding capital beyond that which can be explained by how dairy cooperatives typically interact with dairy farmers or forestry cooperatives interact with forest owners, etc.

Respondents who favoured an individualistic approach to cooperatives tended to be either members of several cooperatives and switched easily, or were not a member of any cooperative. Membership of several or many 
cooperatives was more common among farmers for whom membership appeared almost as arbitrary as well as among those not being a member of any cooperative. Having many memberships and no membership both tended to be statistically correlated to rather low levels of social capital, which can be seen as linking capital. These members had low involvement in the cooperative, possibly of a linking capital-nature. However, the results were somewhat less strong in identifying this group of farmers as also explicit advocates of internationalisation.

An alternative explanation for the weak connection between increasing number of memberships and the lower amount of social capital may be that part-time farmers with small, sometimes diversified, farms rely on the cooperatives' experience as buyers. This saves work and time for them, which may be valuable especially for parttime farmers. If so, there are practical and not ideological reasons, i.e. linking capital (cf. Karantininis and Zago 2001, Nilsson et al. 2012).

More generally, the results indicate that social capital is a multi-dimensional phenomenon that cannot be explained by either farmer or farm characteristics or by cooperative characteristics. The number of memberships could be expected to be an indicator of the farmers' cooperative orientation and hence a dimension of social capital. The data indicated that a larger number of memberships tended to be accompanied by weaker social capital. A cooperatively convinced farmer tends to belong to fewer cooperatives but is then more devoted to these cooperatives, while a less commitment farmer may belong to more cooperatives, each of which is considered to be less important.

The distinction between farmers with traditional cooperative values and high levels of bonding or bridging capital and those with a business orientation and linking capital was less pronounced (in terms of more insignificant explanatory variables) when it came to opinions about cooperatives' foreign investments. Furthermore, farmers with a preference for equality between foreign and domestic farmers supported internationalisation.

These findings indicate that farmers with traditional cooperative values tend to oppose internationalisation. Aversion to internationalisation is in line with bonding or bridging capital, and thus sympathies for traditional cooperatives. However, belonging to another group of farmers who did not share this opinion does not necessarily mean supporting cooperative internationalisation. This group's positive view of internationalisation may depend on whether internationalisation can generate benefits for a specific farm type, as seemed to be the case for diversified farms and, to some degree for larger farmers. A connection between these views and an ideological motivation, or bonding capital, was not indicated by the results.

An alternative interpretation is that the respondents do not pay much attention to their cooperatives' internationalisation strategies. They might see this development as a consequence of the ever-increasing international competition, or it may be considered the task of top managers far away from farmers' day-to-day work (Pyykkönen and Ollila 2012). The latter hypothesis is supported by the seemingly contradiction between the involved members' sceptical opinions about the internationalisation and the fact that these farmers are more likely be elected representatives and thus have decided about the internationalisation.

There may be different explanations. Several explanations for members' low interest for internationalization can be found. One is that the development towards internationalisation has taken place incrementally and at the time of the decision it was impossible to foresee the consequences of the decision (Nilsson et al. 2012). Another one is that the decisions concerning internationalisation and external financing were made as crisis solutions (Pyykkönen and Ollila 2012). A third possibility is that the traditionally oriented members have smaller farms and therefore less likely to become elected representatives.

\section{Conclusions}

The present study aims to explore to which extent farmer cooperatives enjoy social capital within their memberships as these cooperatives are developing towards more internationalised business operations. The empirical basis is a survey among farmers in Finland, the agroindustry of which is highly internationally integrated, having processing operations in most countries around the Baltic Sea. The domestic as well as the foreign processing and marketing activities take most often place in the legal form of limited liability companies, partly co-owned together with external, non-farmer investors.

The findings indicate that bonding and bridging capital is found in the memberships, i.e. there are members who adhere to traditional cooperative values such as equality, loyalty, mutual self-help, equity, and democracy. This is 
even so when the cooperatives' organisational structure deviates clearly from the traditional cooperative model. Under such circumstances one would expect that the cooperatives would enjoy a limited amount of social capital within the memberships.

The amount of social capital is, however, quite unequally distributed among farmer groups. Findings from logit regression models suggest that one group of respondents express much social capital in relation to their cooperative. They embrace a cooperative ideology, are loyal, appreciate the cooperative, etc. These farmers tend to oppose to the cooperatives' foreign investments.

Other farmers have lower levels of social capital. They switch membership status between multiple cooperatives, or opt out of cooperatives. They negotiate with alternative trading partners, searching for short-term good deals. These farmers seem to welcome the cooperatives' investments towards internationalisation. However, this finding was statistically weaker and more specific to farm type than the social capital-related aversion to internationalisation.

In conclusion there are relationships between the amount of social capital (bonding and bridging capital) that the farmers have in relation to their cooperative and their support to the cooperatives' international structures and operations. Farmers who comprise the traditional cooperative model do not appreciate the internationalisation while other farmers are more positive to the development.

A long-lasting and important membership relation with a traditional cooperative is generally regarded to create social capital in the form of trust. When cooperatives are developing their structures increasingly distant from traditional forms, there may be a risk for a divided membership, consisting of both farmers who want to preserve the traditional model and those who support international operations even though this means that the cooperatives have to share the ownership of the operation with external investors. The increased diversity of interests and values within the memberships may pose a threat as it becomes increasingly difficult for the leadership to obtain the necessary interest alignment of different member categories. The ownership costs might thus increase. Due to the foreign operations a cooperative may become so large and so complex that the members have difficulties to govern it.

\section{References}

Adler, P.S. \& Kwon, S.-W. 2002. Social capital: Prospects for a new concept. Academy of Management Review 27: 17-40.

Arcas-Lario, N., Martin-Ugedo, J.F. \& Minguez-Vera, A. 2014. Farmers' satisfaction with fresh fruit and vegetable marketing Spanish cooperatives: an explanation from agency theory. International Food and Agribusiness Management Review 17: 127-146.

Barbaud-Didier, V., Henninger, M.-C., \& El Akremi, A. 2012. The relationship between members' trust and participation in the governance of cooperatives: The role of organizational commitment. International Food and Agribusiness Management Review, 15: 1-24.

Bartkus, V.O. \& Davis, J.H. 2009. Social Capital. Reaching Out, Reaching In. Cheltenham, UK: Edward Elgar.

Barton, D. 1989. Principles. In: D. Cobia (ed). Cooperatives in agriculture. Englewood Cliffs NJ: Prentice-Hall. p. 21-34.

Bhuyan, S. 2007. The people factor in cooperatives: An analysis of members' attitudes and behavior. Canadian Journal of Agricultural Economics, 55: 275-298.

Bhuyan, S. \& Leistritz, F.L. 2001. An examination of characteristics and determinants of success of cooperatives in the non-agricultural sectors. Journal of Cooperatives 16: 46-62.

Bijman, J., Iliopoulos, C., Poppe, K.J., Gijselincks, C., Hagedorn, K., Hanisch, M. Hendrikse, G.W.J., Kühl, R., Ollila, P., Pyykkönen, P., \& Sangen, Ger van der. 2012 b. Support to Farmers' Cooperatives: Final Report. Wageningen, Netherlands: Wageningen UR. 129 p.

Bijman,J., Pyykkönen, P. \& Ollila, P. 2012a. Support for Farmers' Cooperatives; Transnational Cooperatives; EU Synthesis and Comparative Analysis Report. Wageningen, Netherlands, Wageningen UR. 29 p.

Bont, K. de, \& Poppe, K.J. 2012. Support for Farmers' Cooperatives; Case Study Report Hybrid structures in Belgium and The Netherlands. Wageningen: Wageningen UR. 39 p.

Borgen, S.O. 2001. Identification as a trust-generating mechanism in cooperatives, Annals of Public and Cooperative Economics, 72: 209-228.

Bourdieu, P. 1986) The forms of capital. In: J.G. Richardson (ed.) Handbook of theory and research for the sociology of education. Greenwood Press: New York, NY. p. 241-58.

Bravo-Ureta, B.E. \& Lee, T.C. 1988. Socioeconomic and technical characteristics of New England dairy cooperative members and nonmembers. Journal of Agricultural Cooperatives 3: 12-27.

Burt, L.A. \& Wirth, M.E. 1990. Assessing the effectiveness of farm supply cooperatives: a comparison of farmer and manager viewpoints. Journal of Agricultural Cooperatives 5: 17-26.

Cain, J.L., Toensmeyer, U.C. \& Ramsey S. 1989. Cooperative and proprietary firm performance as viewed by their customers. Journal of Agricultural Cooperatives 4: 81-88. 
Calvert, H. 1959. The Law and Principles of Co-operation. 5th ed. Calcutta: Thacker Spink \& Co.

Chaddad, F.R. \& Cook. M.L. 2007. Conversions and other forms of exit in U.S. agricultural cooperatives. In: Karantininis, K. \& Nilsson, J. (eds). Vertical Markets and Cooperative Hierarchies. Dordrecht, Netherlands: Springer: 61-72.

Craig, J.G. 1993. The nature of co-operation. Montréal: Black Rose Books.

Dunn, J. 1988. Basic cooperative principles and their relationship to selected practices. Journal of Cooperation 3: 83-93.

Enander, J., Melin A. \& Nilsson J. (2010). Trust-creating social networks in forest owners' choice of trading partners. Journal of Co-operative Studies 43: 17-28.

Fulton, J.R. \& Adamowicz W.L. 1993. Factors that influence the commitment of members to their cooperative organization. Journal of Agricultural Cooperatives 8: 39-53

Fulton, M.E. \& Hueth, B. 2009) Cooperative conversions, failures and restructurings: an overview. Journal of Cooperatives, 23: i-xi.

Gray, T.W. \& Kraenzle, C.A. 1998. Member participation in agricultural cooperatives. A regression and scale analysis. RBS Research Report 165. Washington D.C.: US Department of Agriculture, Rural Business - Cooperative Service.

Greene, W.H. 2012. Econometric Analysis, $7^{\text {th }}$ Edition. Boston, MA: Pearson.

Fahlbeck, E. (2007). The horizon problem in agricultural cooperatives - Only in theory? In: Karantininis, K. \& Nilsson, J. (eds). Vertical Markets and Cooperative Dordrecht, Netherlands: Springer: 255-274. Dordrecht: Springer

Hakelius, K. 1996. Cooperative values. Farmers' cooperatives in the minds of the farmers. Dissertation 23, Uppsala: Swedish University of Agricultural Sciences, Department of Economics.

Hansen, M.H., Morrow J.L. Jr. \& Batista J.C. 2002. The impact of trust on cooperative membership retention, performance, and satisfaction: an exploratory study. International Food and Agribusiness Management Review 5: 41-59.

Hansmann, H. 1996. The Ownership of Enterprise. Cambridge, MA: Cambridge University Press.

Hendrikse, G.W.J. \& Feng, L. 2013. Interfirm cooperatives. In: A. Grandori (ed.) Handbook of Economic Organization. Cheltenham, UK: Edward Elgar. p. 501-521.

Hess, S., Lind, L.W. \& Liang, S. 2013. Farmers' perceived transaction costs in relation to slaughterhouses of different ownership structures. Agribusiness 29: 96-111.

Hind, A.M. 199). Co-operative life cycle and goals. Journal of Agricultural Economics 50: 536-548.

James Jr., H.S. \& Sykuta, M.E. 2005. Property right and organizational characteristics of producer-owned firms and organizational trust. Annals of Public and Cooperative Economics 76: 545-580.

James Jr., H.S. \& Sykuta, M.E. 2006. Farmer trust in producer- and investor-owned firms: Evidence from Missouri corn and soybean producers. Agribusiness: An International Journal, 22: 135-153.

Jensen, K. 1990. Factors associated with the selection of cooperative vs. proprietary handlers of milk in Tennessee. Journal of Agricultural Cooperatives 5: 27-35.

Karantininis, K., \& Zago, A. 2001. Endogenous membership in mixed duopsonies. Amercan Journal of Agricultural Economics 83 : $1266-1272$.

Klein, K.K., Richards, T.J. \& Walburger, A. 1997. Determinants of co-operative patronage in Alberta. Canadian Journal of Agricultural Economics 45: 93-110.

Lang, K.A. \& Fulton, M.E. 2004. Member commitment and the market and financial performance of the Saskatchewan wheat pool. CAFRI Current Agricultural Food Resource Issues 5: 238.252.

Mensah, E.R., Karantininis, K., Adegbidi, A. \& Okello, J.J. 2012. Determinants of commitment to agricultural cooperatives: cashew nuts farmers in Benin. Conference, August 18-24, 2012, Foz do Iguacu, Brazil No. 125946. International Association of Agricultural Economists.

Misra, S.K., Carley D.H. \& Fletcher, S.M. 1993. Dairy farmers' evaluation of dairy cooperatives. Agribusiness 9: 351-361.

Nilsson, J., Kihlén, A. \& Norell, L. 2009. Are traditional cooperatives an endangered species? About shrinking satisfaction, involvement and trust. International Food and Agribusiness Management Review 12: 103-123.

Nilsson, J., Ollila, P. \& von Brömssen, C. 2011. Characteristics of member loyalty in producer cooperatives. Paper presented in ICA Global Research Conference "New Opportunities for Co-operatives", held in Mikkeli, Finland, on August 24-27

Nilsson, J., Svendsen, G.L.H. \& Svendsen G.T. 2012. Are large and complex agricultural cooperatives losing their social capital? Agribusiness 28: 187-204.

Ollila, P. 1989. Coordination of supply and demand in the dairy marketing system - with special emphasis on the potential role of farmer cooperatives as coordinating institutions. Journal of Agricultural Science in Finland. 61:135-321.

Österberg, P. \& Nilsson, J. 2009. Members' perception of their participation in the governance of cooperatives: The key to trust and commitment in agricultural cooperatives, Agribusiness 25: 181-197.

Payne, G.T., Moore, C.B., Griffis, S.E. \& Autry, C.W. 2011. Multilevel challenges and opportunities in social capital research. Journal of Management 37: 491-520.

Putnam, R.D. 2000. Bowling alone: The Collapse and Revival of American Community. New York: Simon and Schuster. 340 p.

Pyykkönen, P. \& Ollila, P. 2012. Support for farmers cooperatives: Case study report HKScan hybridisation. Wageningen: Wageningen UR. $27 \mathrm{p}$.

Richards, T.J, Klein K.K., \& Walburger, A. 1998. Principal-agent relationships in agricultural cooperatives: An empirical analysis from rural Alberta. Journal of Cooperatives 13: 21-33. 
Robison, L., Siles, M. \& Schmid, A.A. 2002. Social Capital and Powerty Reduction: Toward a Mature Paradigm, Agricultural Economics Report 614. East Lansing, MI: Michigan State University.

Shaffer, J.D. 1987, Thinking about Farmers' Cooperatives, Contracts, and Economic Coordination. Cooperative Theory: New Approaches, ACS Service Report 18, USDA: 61-86.

Staatz, J. 1984. A theoretical perspective on the behavior of farmers' cooperatives. Doctorial dissertation. Michigan State University, East Lansing.

Staatz, J. 1987. The Structural Characteristics of Farmer Cooperatives and their Behavioral Consequences. Cooperative Theory: New Approaches, ACS Service Report 18, USDA: 33-60.

Stickel, D., Mayer, R. \& Sitkin, S. 2009. Understanding social capital: in whom we trust? In: Bartkus, V. and Davis, J. (eds.). Social Capital. Reaching Out, Reaching In. Cheltenham, UK: Edward Elgar: p. 304-318.

Woolcock, M. 1998. Social capital and economic development: Towards a theoretical synthesis and policy framework. Theory and Society 27: 151-208.

Zeuli, K.A. \& Bentancor, A. 2005. The effects of cooperative competition on member loyalty. Annual Meeting, November 8-9 No. 31823. NCERA-194 Research on Cooperatives. 


\section{Appendix: Explanatory Variables}

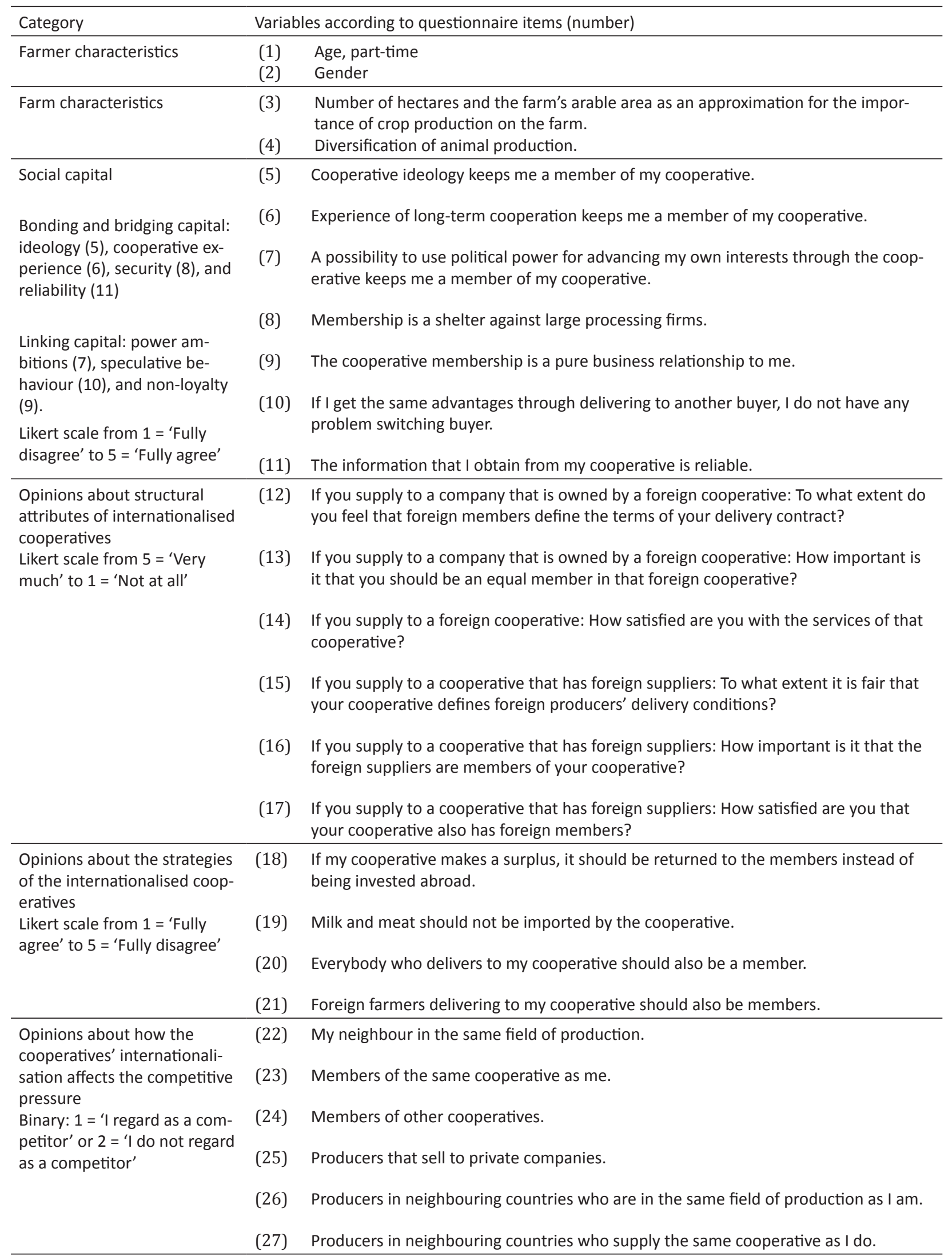
Note: Cronbach's Alpha / Share of variance explained by first for groups of variables 5,6,8,11=0.93 / 81,12; 7,9,10=0.79/70,97; 12$17=0.81 / 65.97 ; 18-21=0.90 / 76.98 ; 22-27=0.90 / 67.54$. 